\title{
Kocaeli Example: the Relationship Between Exam Anxiety and Self- Confidence States of Sports High School Students
}

\author{
Tolga Kaan Bahadir ${ }^{1}$, Bahadir Aligül $^{2}$, \\ ${ }^{1}$ Kocaeli University, Turkey \\ ${ }^{2}$ Kocaeli Provincial Directorate of Youth and Sports, Turkey \\ Study Area: Kocaeli, Turkey \\ Coordinates: $40.852^{\circ} \mathrm{N} ; 29.878^{\circ} \mathrm{E}$
}

Key words:

\section{Abstract}

A total of 175 students randomly selected ( 98 boys and 77 girls) studying at Kocaeli Hayrettin Gürsoy Sports High School in Kartepe district of Kocaeli province. Qualitative data collection method was used in this study. In the study, Personal Data Form, self-confidence scale, exam anxiety (attitude) inventory (SKE). It has been observed that participants had significant differences between gender, licensed sports status, father's profession, mother's profession, family material income status, as well as levels of self-confidence and exam anxiety. In addition, it was concluded that there was a negative correlation between exam anxiety levels and self-confidence States of the subjects participating in the study. Finally, while no correlation relationship was found from exam anxiety according to the age variable, self-confidence was observed to be a positive significant relationship related to family.

and ideas about the exam that they will take and experiences distraction. The other dimension is sensuality. Sensuality is a condition in which a person is physiologically affected during the exam. Heart rate acceleration, nausea and vomiting sensation, excessive nerves, and chills, headache can be given as an example of this issue (Spielberger \& Vogg, 1995).

Exam anxiety is very important at the point of one's success. Some studies on this include. In a study by Wine (1980), he emphasized the importance of attention in exam anxiety. People with high anxiety tend to focus some of their attention on the delusional state, which is the lower length of exam anxiety, and give their actual attention to subjects outside the exam. He said that this topic will reduce the level of success in the exam that a person will take.

In another study, they have observed that people who failed the exam lack information, did not study the exam, perceived the exam as a very diff icult situation, experienced distraction during the exam, could not reflect their abilities on the exam, and experienced intense negative emotions during the exam(Cooley \& Spielberger, 1980; Birenbaum \& Nasser, 1994; Hong, 1999; Sullivan, 2002; Cassady, 2004).

Self-confidence is the fact that a person knows the abilities that exist within themselves and believes that they can use these abilities. Self-confidence is the first dimension of one's awareness, that is, the situation to recognize oneself. Second, he knows where, how, when, and 
at what level to achieve these characteristics. The concept of self-confidence is summed up in two sub-dimensions, internally and externally. Internal self-confidence is a condition related to the person's own, while external selfconf idence is the life process in which the person is affected by external factors. (Akin, 2007).

One of the biggest problems today is the lack of selfconfidence in children. There are many reasons for this. When we come to these reasons, most importantly, it is a process that starts with the family and then continues at school.

First of all, the family's approach to children will be the determinant of the child's concept of self-confidence. If we need to talk about these approaches, we can say that the family exaggerates the protectionist structure and interferes with every issue related to the child (Yavuzer, 1990). In the sequel, the negative effects of the family's erratic behavior on the child are revealed. The fact that the family sometimes understanding their children very well, sometimes very disciplined, will create imbalances in the child. In other words, the family is tolerant of the same subject on another day when they are angry about one subject (Eksi, 1990). Another situation is that as a result of the family interfering with every issue related to the child, the child becomes a person with low self-confidence and a highly emotional personality structure that will arise (Aslan, 1992). In the opposite case, there should be families who can be responsible for their children when they have a balanced place, do not discriminate within their children, required given them confidence. The active role of mother and father in the family is very important. Problems who lives especially the families are divorced, death and similar incidents, especially the father's indifference towards his children, pressure and frightening, will cause him to grow up timid and insecure (Yavuzer, 1990; Geçtan, 1984; Kulaksizoglu, 1999; Yörükoglu, 1986; Kaya et al., 1992).

Another factor is a person's school, environment and self-perception is form. The attitude of the teacher in the school is one of the processes that will guide the child's future. Of course, it is able to display to analyze the structure of thought that he will receive from the environment in this regard and that the child will receive both with himself and with his peers well in himself and demonstrate the right attitude. Self-conf ident individuals especially do not live fully dependent on their environment and peers. they exhibit the necessary posture and emotional resistance when it comes to a place (Yörükoglu, 1986; Akagündüz, 2006; Yavuzer, 1990). Finally, it is the participation of the individual in the activities. With these activities, the individual can realize himself in social environments, keep up with social environments, develop himself by having many features such as trusting the other person. Because of this, participation in events such as sports, art, music is very important (Ozer, 1990).

\section{Methodology \& Findings:}

The research group consists of a total of 175 students of 98 randomly selected boys and 77 girls studying at Kocaeli Hayrettin Gürsoy Sports High School in the Kartepe district of Kocaeli province. A qualitative data collection method was used in this study. As the data collection instrument created by the researcher in the study "Personal Information Form" for determining the level of confidence of the participants the flock (2007) developed by validity and reliability studies of the self-esteem scale (intrinsic and extrinsic as the two sub-dimensions) was used. The scale has 33 items and 2 sub-dimensions. It is a likert-type scale with 5. An inventory of exam anxiety (attitude) (SKE), developed by Öner (1990) and conducted a study of validity and reliability, was used to determine the participants ' level of attitude to exam anxiety. The scale has 20 items and 2 sub-dimensions(delusion and affective). 4 ' is a likert-type scale. In the analysis section of the study, the Spss-2o package program was used. Before the analysis of the data, the data was applied by applying a normality test, and because the data did not show a normal distribution, the analysis was performed by nonparametric tests. In the analysis part of the data, descriptive statistics frequency(n) and percentage $(\%)$ values were calculated. Besides, Mann Whitney- $\mathrm{U}$ and Kruskal Wallis $\mathrm{H}$ tests were performed to find the difference between the independent variables in the study. In the variables from which the significant difference originates, the Bonferroni method was used to determine the group from which the difference originates. Finally, a Spearman correlation test was performed on dependent variables. The meaning level of the study was accepted as $\mathrm{p}<0.05$.

\section{Result:}

Table-1: Mann whitney-U results by Gender Variable

\begin{tabular}{lllllll}
\hline Variable & Sex & $\mathrm{N}$ & $\begin{array}{l}\text { Mean } \\
\text { Rank }\end{array}$ & $\begin{array}{l}\text { Sum } \\
\text { Rank }\end{array}$ & U & P \\
\hline In self- & male & 98 & 101.75 & 9971.5 & -4.11 & o.oo* $^{*}$ \\
confidence & female & 77 & 70.5 & 5428.5 & & \\
Outside & male & 98 & 112.69 & 11044 & -7.31 & o.oo* $^{*}$ \\
self-confidence & female & 77 & 56.57 & 4356 & & \\
Total self- & male & 98 & 112.6 & 11035 & -7.26 & o.oo* $^{*}$ \\
confidence & female & 77 & 56.69 & 4365 & & \\
Delusion & male & 98 & 57.68 & 5653 & -9.07 & o.oo* $^{*}$ \\
Affectivity & female & 77 & 26.58 & 9747 & & \\
& male & 98 & 61.24 & 6002 & -7.94 & o.oo* $^{*}$ \\
Total & female & 77 & 122.05 & 9398 & & \\
Exam anxiety & male & 98 & 57.46 & 5631 & -9.04 & o.oo* $^{*}$ \\
& female & 77 & 126.87 & 9769 & & \\
\hline
\end{tabular}

Significant differences were observed in both selfconf idence and exam anxiety states according to the gender variable of the subjects participating in the study (Table-1). Male students ' self-confidence rank averages were higher 
than female students. In the exam anxiety scores, the average ranking of female students was higher than that of male students.

Table-2: Mann whitney-U results according to the licensed sports status of the participants

\begin{tabular}{|c|c|c|c|c|c|c|}
\hline Variable & Sex & $\mathrm{N}$ & $\begin{array}{l}\text { Mean } \\
\text { Rank }\end{array}$ & $\begin{array}{l}\text { Sum } \\
\text { Rank }\end{array}$ & $\mathrm{U}$ & $\mathrm{P}$ \\
\hline \multirow{4}{*}{$\begin{array}{l}\text { Internal self- } \\
\text { confidence } \\
\text { External } \\
\text { self-confidence }\end{array}$} & Yes & 135 & 93.33 & 12.600 & \multirow[t]{2}{*}{-2.59} & \multirow[t]{2}{*}{$0.01^{*}$} \\
\hline & no & 40 & 70.00 & 2.800 & & \\
\hline & Yes & 135 & 100.02 & 13.502 & \multirow[t]{2}{*}{$-5 \cdot 79$} & \multirow[t]{2}{*}{$0.00^{*}$} \\
\hline & No & 40 & $47 \cdot 44$ & 1.897 & & \\
\hline \multirow{2}{*}{$\begin{array}{l}\text { Total self- } \\
\text { confidence }\end{array}$} & Yes & 135 & 99.11 & $13 \cdot 380$ & \multirow[t]{2}{*}{$-5 \cdot 34$} & \multirow[t]{2}{*}{$0.00^{*}$} \\
\hline & No & 40 & 50.50 & 2.020 & & \\
\hline \multirow[t]{2}{*}{ Delusion } & Yes & 135 & 79.27 & 10.701 & \multirow[t]{2}{*}{-4.25} & \multirow[t]{2}{*}{$0.00^{*}$} \\
\hline & No & 40 & $117 \cdot 46$ & 4.698 & & \\
\hline \multirow[t]{2}{*}{ Affectivity } & Yes & 135 & 80.99 & 10.933 & \multirow[t]{2}{*}{$-3 \cdot 39$} & \multirow[t]{2}{*}{$0.00^{*}$} \\
\hline & No & 40 & 111.68 & 4.467 & & \\
\hline \multirow{3}{*}{$\begin{array}{l}\text { Total } \\
\text { Exam anxiety }\end{array}$} & Yes & 135 & 80.43 & 10.857 & -3.65 & \multirow[t]{3}{*}{$0.00^{*}$} \\
\hline & female & No & 40 & 113.56 & \multirow{2}{*}{$\begin{array}{c}4.542 \\
5^{* *} \mathrm{p}<.001\end{array}$} & \\
\hline & Total & 175 & & & & \\
\hline
\end{tabular}

Significant differences were observed in both selfconfidence and exam anxiety states according to the status of the licensed sport of the subjects participating in the study (Table-2). The average self-confidence rating of students engaged in licensed sports was higher than that of students not engaged in licensed sports. In the case of exam anxiety, the average ranking of students who did not play licensed sports was higher than students who have not to play licensed sports.

Table-3: Kruskal wallis $\mathrm{H}$ test results according to the paternal occupation status of the participants

\begin{tabular}{|c|c|c|c|c|c|c|c|}
\hline \multicolumn{2}{|c|}{ Father's Profession } & $\mathrm{N}$ & Mean & SD & $x^{2}$ & $\mathrm{P}$ & Sig. Diff. \\
\hline \multirow{3}{*}{$\begin{array}{l}\text { Internal self- } \\
\text { confidence }\end{array}$} & 1-worker & 21 & 74.07 & 2 & 3.536 & 0.171 & \\
\hline & 2-selfemp. & 81 & 84.94 & & & & \\
\hline & 3-officer & 73 & $95 \cdot 4$ & & & & \\
\hline \multirow{3}{*}{$\begin{array}{l}\text { External } \\
\text { self-confi- } \\
\text { dence }\end{array}$} & 1-worker & 21 & 74.05 & 2 & 34.977 & $.000^{*}$ & \\
\hline & 2-self emp. & 81 & $67 \cdot 7$ & & & & $2^{* *}-3$ \\
\hline & 3-officer & 73 & 114.54 & & & & \\
\hline \multirow{3}{*}{$\begin{array}{l}\text { Total self- } \\
\text { confidence }\end{array}$} & 1-worker & 21 & 70.57 & 2 & 25.286 & $.000^{*}$ & \\
\hline & 2-self emp. & 81 & 72.04 & & & & $2^{* *}-3$ \\
\hline & 3-officer & 73 & 110.73 & & & & \\
\hline \multirow[t]{3}{*}{ Delusion } & 1-worker & 21 & $105 \cdot 79$ & 2 & 50.437 & $.000^{*}$ & $1^{* *}-3$ \\
\hline & 2-self emp. & 81 & 111.84 & & & & $2^{* *}-3$ \\
\hline & 3-officer & 73 & 56.43 & & & & \\
\hline \multirow[t]{3}{*}{ Affectivity } & 1-worker & 21 & 73.62 & 2 & 32.61 & $.000^{*}$ & \\
\hline & 2-self emp. & 81 & 111.27 & & & & $2^{* *}-3$ \\
\hline & 3-officer & 73 & 66.32 & & & & \\
\hline \multirow{4}{*}{$\begin{array}{l}\text { Total } \\
\text { Exam } \\
\text { anxiety }\end{array}$} & 1-worker & 21 & $89 \cdot 33$ & 2 & 45.179 & $.000^{*}$ & $1^{* *}-3$ \\
\hline & 2-self emp. & 81 & 113.73 & & & & $2^{* *}-3$ \\
\hline & 3-officer & 73 & 59.06 & & & & \\
\hline & & 175 & & & ${ }^{*} \mathrm{P}<.0$ & ${ }^{* x} \mathrm{p}<$ & \\
\hline
\end{tabular}

There were significant differences in both the selfconfidence sub-dimensions, external self-confidence dimension and total self-confidence, and exam anxiety according to the fathers' professions of the subjects participating in the study (Table-3). The average rank of external self-confidence and total self-confidence was higher for fathers whose fathers were self-employed. In addition, the average rank of delusions, affectivity and total test anxiety, whose fathers' were civil servants, were found to be lower than those whose fathers were self-employed. Lastly, the average rank of delusions and total exam anxiety was lower for fathers working as infant workers.

Table-4: Kruskal wallis $\mathrm{H}$ test results according to the maternal occupation status of the participants

\begin{tabular}{|c|c|c|c|c|c|c|c|}
\hline Mother's Pro & ession & $\mathrm{N}$ & Mean & SD & $x^{2}$ & $\mathrm{P}$ & Sig. Diff. \\
\hline Internal self- & 1-worker & 114 & 106.09 & & & & $1^{* *}-3$ \\
\hline confidence & 2-selfemp. & 28 & $77 \cdot 3$ & 2 & 53.88 & $.00{ }^{*}$ & $2^{* *}-3$ \\
\hline & 3-officer & 33 & $34 \cdot 59$ & & & & \\
\hline External & 1-worker & 114 & 86.47 & & & & \\
\hline self-confi- & 2-self emp. & 28 & 76.48 & 2 & 4.505 & 0.105 & \\
\hline dence & 3-officer & 33 & 103.05 & & & & \\
\hline Total self- & 1-worker & 114 & 94.09 & & & & \\
\hline confidence & 2-self emp. & 28 & 77.89 & 2 & $4 \cdot 775$ & 0.092 & \\
\hline & 3-officer & 33 & $75 \cdot 53$ & & & & \\
\hline Delusion & 1-worker & 114 & 95.19 & & & & $1^{* *}-3$ \\
\hline & 2-self emp. & 28 & $117 \cdot 5^{2}$ & 2 & 45.216 & $.000^{*}$ & $2^{* *}-3$ \\
\hline & 3-officer & 33 & 38.11 & & & & \\
\hline Affectivity & 1-worker & 114 & 90.92 & & & & \\
\hline & 2-self emp. & 28 & 96.63 & 2 & 5.151 & 0.076 & \\
\hline & 3-officer & 33 & 70.61 & & & & \\
\hline Total & 1-worker & 114 & 95.7 & & & & $1^{* *}-3$ \\
\hline Exam & 2-self emp. & 28 & 108.29 & 2 & 32.107 & $.000^{*}$ & $2^{* *}-3$ \\
\hline anxiety & 3-officer & 33 & 44.2 & & & & \\
\hline & Total & 175 & & & ${ }^{*} \mathrm{P}<$. & ${ }^{*} \mathrm{p}<. \mathrm{oc}$ & $\mathrm{D} 1$ \\
\hline
\end{tabular}

Table-4: Kruskal wallis $\mathrm{H}$ test results according to the maternal occupation status of the participants

\begin{tabular}{|c|c|c|c|c|c|c|c|}
\hline Tothe & ofession & $\mathrm{N}$ & Mean & & & $\mathrm{P}$ & \\
\hline $\begin{array}{l}\text { Internal } \\
\text { self- } \\
\text { confidence }\end{array}$ & $\begin{array}{l}\text { A-0-2.325TL } \\
\text { B-2.326-5.00o TL } \\
\text { C-5.001- 10.00oTL }\end{array}$ & $\begin{array}{l}28 \\
107 \\
40\end{array}$ & $\begin{array}{l}87.54 \\
100.95 \\
53.69\end{array}$ & 2 & 26.029 & $000^{*}$ & $\begin{array}{l}\mathrm{A}^{* *}-\mathrm{C} \\
\mathrm{B}^{* *}-\mathrm{C}\end{array}$ \\
\hline $\begin{array}{l}\text { External } \\
\text { self- } \\
\text { confidence }\end{array}$ & $\begin{array}{l}\text { A-o }-2.325 \mathrm{TL} \\
\text { B-2.326-5.000 TL } \\
\text { C-5.001- } 10.000 \mathrm{TL}\end{array}$ & $\begin{array}{l}28 \\
107 \\
40\end{array}$ & $\begin{array}{l}39,79 \\
90.55 \\
114.94\end{array}$ & 2 & $37 \cdot 302$ & $.000^{*}$ & $C^{* *}-A$ \\
\hline $\begin{array}{l}\text { otal self- } \\
\text { onfidence }\end{array}$ & $\begin{array}{l}\text { A-o }-2.325 \text { TL } \\
\text { B-2.326-5.000 TL } \\
\text { C -5.001- 10.000 TL }\end{array}$ & $\begin{array}{l}28 \\
107 \\
40\end{array}$ & $\begin{array}{l}45,73 \\
97 \cdot 51 \\
92.15\end{array}$ & 2 & 4 & $.000^{*}$ & $\mathrm{C}^{* *}-\mathrm{A}$ \\
\hline elusion & $\begin{array}{l}\text { A -o - 2.325 TL } \\
\text { B-2.326-5.000 TL } \\
C-5.001-10.000 \text { TL }\end{array}$ & $\begin{array}{l}28 \\
107 \\
40\end{array}$ & $\begin{array}{l}152.68 \\
85.65 \\
49.01\end{array}$ & 2 & .788 & $\mathrm{ooo}^{*}$ & $\begin{array}{l}\mathrm{A}^{* *}-\mathrm{B} \\
\mathrm{B}^{* *}-\mathrm{C} \\
\mathrm{C}^{* *}-\mathrm{A}\end{array}$ \\
\hline fectivity & $\begin{array}{l}\text { A -o - 2.325 TL } \\
\text { B -2.326-5.00o TL } \\
C-5.001-10.000 \mathrm{TL}\end{array}$ & $\begin{array}{l}28 \\
107 \\
40\end{array}$ & $\begin{array}{l}139.59 \\
83.13 \\
64.93\end{array}$ & 2 & 38.861 & $.000^{*}$ & $\begin{array}{l}\mathrm{A}^{* *}-\mathrm{B} \\
\mathrm{B}^{* *}-\mathrm{C} \\
\mathrm{C}^{* *}-\mathrm{A}\end{array}$ \\
\hline $\begin{array}{l}\text { otal } \\
\text { xam } \\
\text { nxiety }\end{array}$ & $\begin{array}{l}\text { A -o - 2.325 TL } \\
\text { B -2.326-5.00o TL } \\
\text { C -5.001- 10.00o TL } \\
\text { Total }\end{array}$ & $\begin{array}{l}28 \\
107 \\
40 \\
175\end{array}$ & $\begin{array}{l}146.79 \\
86.93 \\
49.7\end{array}$ & 2 & $\mathrm{P}<$. & $00^{*}$ & $\begin{array}{l}A^{* *}-B \\
B^{* *}-C \\
C^{* *}-A\end{array}$ \\
\hline
\end{tabular}

Looking at the pre-test post-test values of the variables in Table-1, it was found that there was no significant difference between the right and left-hand grip strength pre-test post-test values. It was observed that there was a significant increase at $\mathrm{p}<0.05$ level between leg pre-test 
post-test strengths. It was determined that there was a significant $(\mathrm{p}<0.01)$ difference between the pretest and posttest values of othervariables in favour of the post-test.

It was observed that the subjects participating in the study had confidence and exam anxiety according to their financial status (Table-5). When exam anxiety of students was examined, financial income was slightly higher than those with 0-2325 TL, student family financial situation 2325 TL-5000, 5001-10,000 TL according to the rankings of delusion, affectivity and total exam anxiety. In addition, it was found to be lower in terms of rank compared to students whose family financial situation was between 5001-10.000 TL and whose family financial situation was between 2325 TL-5000.

Table 6. Spearman's rho correlation test results of participants ' self-confidence and exam anxiety states

\begin{tabular}{|c|c|c|c|c|}
\hline & & Int. Self-Conf & Ext. Self-Con. & Total Self-Conf. \\
\hline \multirow[t]{2}{*}{ Delusion } & $\mathrm{r}$ & -0.08 & $-.518^{* *}$ & $-.418^{* *}$ \\
\hline & $\mathrm{p}$ & 0.33 & 0,00 & 0,00 \\
\hline \multirow[t]{2}{*}{ Affectivity } & $\mathrm{r}$ & $-.413^{* *}$ & $-.672^{* *}$ & $-.631^{* *}$ \\
\hline & $\mathrm{p}$ & 0.00 & 0.00 & 0.00 \\
\hline \multirow[t]{2}{*}{ Total exam anxiety } & $\mathrm{r}$ & $-.189^{*}$ & $-.592^{* *}$ & $-.496^{* *}$ \\
\hline & $\mathrm{p}$ & 0.01 & 0.00 & 0.00 \\
\hline
\end{tabular}

It was observed that there was a negative significant relationship between the test anxiety states of the subjects, affective and total test anxiety, and their external self-confidence and total self-conf idence scores (Table-6).

Table-7: Spearman's rho correlation test results of exam anxiety states with age of participants

\begin{tabular}{|c|c|c|c|c|c|c|}
\hline & $\begin{array}{l}\text { Int. Self- } \\
\text { Confidence }\end{array}$ & $\begin{array}{l}\text { Ext. Self- } \\
\text { Confidence }\end{array}$ & $\begin{array}{l}\text { Total Self- } \\
\text { Confidence }\end{array}$ & $\begin{array}{l}\text { Delus. } \\
\text { sion }\end{array}$ & $\begin{array}{l}\text { Affect. } \\
\text { ivity }\end{array}$ & $\begin{array}{l}\text { Total Exam } \\
\text { Anxiety }\end{array}$ \\
\hline $\mathrm{r}$ & $.255^{* *}$ & .071 & .118 & .088 & -.091 & -.078 \\
\hline $\mathrm{p}$ & .001 & .348 & .120 & 250 & $\begin{array}{l}.231 \\
{ }^{*} \mathrm{P}<.05\end{array}$ & $\begin{array}{l}.302 \\
* * \\
\mathrm{p}<.01\end{array}$ \\
\hline
\end{tabular}

No relationship was found between the age variables of the subjects participating in the study and their test anxiety, while a positive significant relationship was found in the self-confidence sub-dimensions, in particular the self-confidence dimension (Table-7).

\section{Discussion :}

Looking at the results of the study, we can say that the selfconfidence levels of students attending sports High School vary according to gender. In the gender factor special, male students have higher levels of internal, external and total self-confidence than female students. The reason for this is that the number of male students engaged in licensed sports is greater than the number of female students, and the child of the surrounding sports clubs is much higher than the male branch. In addition, a positive significant association was found between the age variable and internal self-confidence from the lower dimensions of selfconfidence. Some studies that parallel the result we found areas follows.

A significant difference has been found between the sexes in affective, delusional, and total exam anxiety values (Senel et al., 2014). Laskovic et al. (1990), found a significant relationship between the variables of age and gender and their self-confidence status on 399 students in groups between 13 and 17. According to Zorba, (2012) the individuals who participate in sports develop their own selves in a positive way, and thus their self-confidence status increases.

Another result of our research is that the selfconfidence status of Sports High School students differs depending on their licensed sports and non-sports status. Students who played licensed sports had higher selfconfidence than students who did not play sports. The reason for this is that sports are thought to be at the top of the fields in which students who play sports can realize themselves, create self-esteem, recognize themselves and feel valuable. The reason for this is that sports are thought to be at the top of the fields in which students who play sports can realize themselves, create self-esteem, recognize themselves and feel valuable. This makes a serious contribution to the self-confidence of the student. Some studies that show similarities to this result are as follows:

He believes that through sports, individuals learn to share, realize themselves, believe in themselves, and this has a self-confidence-building effect on the person. Thanks to this situation, it also causes the entrepreneurial characteristics of individuals to come to the fore (Güngörmüs, 1988; Yavuzer, 2005).

Another result that we have achieved is that Sports High School students have significant differences in their father's profession, mother's profession, and family income status related to self-confidence. In particular, among the results we obtained, it was concluded that the fathers of students whose father was an officer were workers and selfemployed, and the mothers of students whose mothers were housewives had a high level of self-confidence compared to those who were workers and officers. It is believed that both the professional and financial difficulties of their parents may be negative factors that will create on students. Examples of these factors are the intensive pace of work of families, the inability of family members to spend quality time with each other due to shift work, the lack of the family's monthly income to provide for the family, the decline in purchasing power with the increase in the country's inflation rates.

According to Yavuzer (2005), for the child, the father is very important in terms of emotional and social development. Ozturk (2017), showed a significant relationship between the role and approaches determined by families and self-confidence. It is the family's financial return and support, self-use, personal development and development of behaviour specif ic to it.

Looking at the results of our research on exam anxiety; It was observed that there were differences in exam 
concerns according to the gender variable of the subjects participating in the study and according to the status of the students playing licensed sports. Female students have higher exam anxiety status in the gender variable than male students. But delusional male students have a higher state of anxiety than female students. According to the status of licensed sports, students who played licensed sports had lower exam concerns than students who did not. The reason for this is that sports are thought to help students balance their anxiety States by thinking that they improve on many issues in a psychological sense. We have said that female students have higher anxiety about exam anxiety. We think that the reason for this is that female students ' personality structures are more sensitive and more emotional than male students and that pressure and stressful environments affect them more negatively. Studies like this are as follows.

Frydenberg \& Lewis (1993) found that girls are more concerned than boys because they that has been decided girls find themselves at fault with their problems and get support from the environment for this. Students whose father was a civil servant were found to have lower levels of exam anxiety than those whose father was a worker and selfemployed. In addition, the mothers of students whose mother was a housewife and a worker have higher exam anxiety than those whose mothers were civil servants. In addition, the mothers of students whose mother was a housewife and a worker have higher exam anxiety than those whose mothers were civil servants. The reason for this is due to certain situations brought by professions. For example, families of civil servants often have leisure time outside of work and on weekends compared to other occupational groups. Holiday times can also take a long time in general. In this situation, we can consider the possibility that families with an off icer family structure can use their free time more effectively to spend time on their children, meeting their children's needs.

Varol (1990), determined that those who were selfemployed with officers, officers in the paternal profession had low anxiety levels compared to students who were workers, farmers, artisans in the paternal profession. It was found that the anxiety levels of the students who were selfemployed in their mother's profession were lower than those whose mother's profession was housewife, worker, and tradesman.

It is very important that the child experiences from childhood in the formation of anxiety. Family structure, economic status, number of siblings, level of education of the family, especially in the family mother and father's work in stressful jobs due to their profession is a difficult situation for the family (Alisinanoglu \& Ulutas, 200o).

One of the findings of the study is that there was no significant relationship between the self-confidence dimension of Sports High School students from the lower dimensions of self-confidence and the delusion dimension from the lower dimensions of exam anxiety. But it has been found that there is a negative significant relationship between the level of externality and total self-conf idence in the sub-dimension of self-confidence and the level of Affective and total exam anxiety in the sub-dimension of exam anxiety. The reason for this is that people with high self-confidence, especially in situations such as exam anxiety, can think that they throw stress on themselves by thinking more logically and mature.

Conclusivly, sports increase self-confidence and reduce anxiety gender, family economic status, family profession variables affect self-conf idence and exam anxiety states. We can say that there is a negative relationship between selfconfidence and exam anxiety...

Suggestions:

$\uplus_{-}$-Particular attention should be paid to improving the selfconfidence of high school students and reducing their exam anxiety.

4 -High school students can be supported not only in sports but also in the fields of culture, art, music, where they can develop themselves.

$\Leftrightarrow$-Guidance services can be provided to the families of high school students using the guidance services of schools.

$\rightarrow$-High school students should be supported to cope with situations such as negativity, stress and anxiety that they will experience during adolescence

$\rightarrow$-Most importantly, families can work to provide the right approach to their children, that is, the right sources of communication.

\section{References:}

Akagündüz, N. (2006): Insan yasaminda özgüven kavrami. Istanbul: Ümraniye Rehberlik ve Arastirma Merkezi Müdürlügü Yayinlari, (1).

Akagunduz, N. (2006): The Concept Of Self-Confidence In Human Life, Ümraniye guidenceand Research Center Directorate publications, Issue: 1 , Istanbul.

Akin, A. (2007) development of the self-confidence scale and its psychometric properties. L. Fac. Edu Abant Izzet Baysal Univers., 7:167-176.

Alisinanoglu, f. \& Ulutas, I. (200o): Anxiety in children and factors affecting it. L. Nat. Edu., 145:15-19.

Aslan, E. (1992): The concept of self and its effects on the life of the individual", L. Edu. Sci. Marmara Univers., 4.

Baltas A. \& Baltas Z. (1998): Ways to cope with stress to be successful and healthy. Pub. By: Remzi Kitabevi publications, Istanbul.

Birenbaum, M.,\&Nasser, F. (1994): On therelationshipbetween test anxietyand test performance. Measure. Evaluat. Coun. Devel., 27:293-302.

Cassady, C.J. (2004): Theinfluence of cognitive test anxiety across the learning- testing cycle. Learn. Instruc., 14:569-572.

Cooley, J.E. \& Spielberger, C.D. (1980): Cogntive versus emotional coping responses as alternatives to test anxiety. Cogn. Therapy 
Res., 4:459-466.

Eksi, A. (1990): Children, Teenagers, Parents. Pub. By:Bilgi Publishing House, Ankara.

Frydenberg, E. \& Lewis, R. (1993): Boys play sport and girls turn to others: Age, gender, and ethnicity as determinants of coping. L. Adol., 16:252-266.

Geçtan, E. (1984): Contemporary life and abnormal behavior, third edition, Pub. By: Maya Publications, Ankara.

Hong, E. (1999). Test anxiety, percieved test difficultyand test performance patterns of their effects. Learn. Ind. Diff., 11:431447.

Kaya, N., Ulusoy, M., \& Aral, F. (1992): Child mother and beating pp. 23-27. Congressional Book of Days of Child and Adolescent Psychiatry.

Köknel, Ö.( 1987): Stress In The Age OfAnxiety. Pub. By: Golden Books Publishing House, Istanbul, Turkey.

Lackovic-Grgin, K. \& ve Dekovic, M. (1990). The contribution of significant others to adolescents' self- esteem. Adolescence, 25(100), 839-846.

Öner, N. (1990): Handbook of exam anxiety inventory. Foundation for the dissemination of guidance in higher education publication No:1. . Istanbul.

Özer, K. (1990): Anxiety about Testing and Testing. Pub. By: Entity Publications.

Öztürk, N. (2017): A study of the relationship between the family climate perceived by university students and their attachment to parents and their level of self-conf idence. J. Int. Ling. Soc. Edu. Sci., 3(1):9-22.
Spielberger. C. \& Vagg, R. (1995): Test Anxiety: Theory, Assessment and Treatment. Pub. By: Taylor and Francis.

Senel, E., Yeniyol, C., Köle, Ö., Adilogullari, I. (2014): Examination of the Relation Between School of Physical Education and Sport Students' Approach to Learning and Studying and Test Anxiety. Nigde Univers. J. Phys. Edu. Sport Sci., 8(1):140-148.

Sullivan, L. (2002): The effect of test anxiety on attentionandmemoryskills in undergraduatestudents. Chrestomatly: Ann. Rev. Undergraduate Res Coll. Cherleston, 1:263-273.

Varol, S., (1990): Factors Affecting The Concerns Of High School Seniors. Unpublished master's thesis. University. Samsun.

Wine, J.D. (1980): Cognitive attentional theory of test anxiety. In. I.G. Sarason (Ed.). Test Anxiety: Theory, Research, and Applications. Pub. By: Hilldale, New Jersey: Lawrence Erlbaum AssociatesInc.,Publishers.

Yavuzer, H. (2005): Understanding Young People, First Edition. Pub. By: Remzi Bookstore, Istanbul.

Yavuzer, H. (1990): Parents ' School. Pub. By: Remzi Kitabevi. Istanbul.

Yörükoglu, A. (1986): The age of youth. Business Bank of Turkey cultural publications series of social and philosophical works, 26. Ankara.

Zorba, E. (2012): Lifelong sports for all. Pub. By: Neyir Publications, Ankara. 